\title{
Australian Aboriginal plant foods: a consideration of their nutritional composition and health implications
}

\author{
Janette C. Brand-Miller and Susanne H. A. Holt \\ Human Nutrition Unit, Department of Biochemistry, University of Sydney, NSW and \\ CSIRO Division of Human Nutrition, Adelaide, SA, Australia
}

\begin{abstract}
For at least $40-50000$ years, plants played an important but supplementary role in the animal-dominated diet of Australian Aboriginal (AA) hunter-gatherers. New knowledge of the nutrient composition and the special physiological effects of their foods provides another perspective in the current debate on the composition of the 'prudent' diet and the diet on which humans evolved. In the present paper we have calculated the average nutrient composition of over 800 Aboriginal plant foods (in total and by food group) and highlighted the differences between these and modem cultivated foods. The data enable us to calculate the absolute contribution of plant foods to total food and nutrient intake of traditional living AA. If plants provided $20-40 \%$ of the energy in the diet (the most likely range), then plants would have contributed $22-44 \mathrm{~g}$ protein, $18-36 \mathrm{~g}$ fat, $101-202 \mathrm{~g}$ carbohydrate, $40-80 \mathrm{~g}$ fibre and $90-180 \mathrm{mg}$ vitamin $C$ in a $12500 \mathrm{~kJ}$ (3000 kcal) diet. Since all the carbohydrate came from plant foods, the traditional AA diet would have been relatively low in carbohydrate (especially starch) but high in dietary fibre in comparison with current recommendations. Over half the carbohydrate could have been in the form of sugars derived from fruit and honey. The low glycaemic index of their carbohydrate foods, however, would generate a relatively low demand for insulin secretion and this characteristic may have protected AA from a genetic predisposition to insulin resistance and its consequences (non-insulin-dependent diabetes mellitus, coronary heart disease, obesity). The dietary pattern and active lifestyle of recent hunter-gatherers such as AA may be a reference standard for modern human nutrition and a model for defence against diseases of affluence.
\end{abstract}

\section{Introduction}

The ancestors of Australian Aboriginal (AA) people migrated to Australia from South-East Asia at least 40-50000 years ago (Flood, 1995). They led a nomadic hunter-gatherer lifestyle until only 200 years ago when European settlement of Australia began. Plants played an important supplementary role in the animal dominated diet of these nomadic peoples, who never adopted agriculture (Lee, 1996). Apart from nutrition, plants provided medicines and the raw materials to make tools, weapons, poisons, food utensils and objects of art. Some groups of AA were isolated from the effects of European ways until the middle of this century. The written records of their lifestyles and food habits provide a unique glimpse of how early 
humans may have existed during palaeolithic times (the period stretching from the first manufacture of stone tools around 400000 years ago to just before the advent of agriculture 10000 years ago). The plant foods that were consumed by recent traditional-living AA are likely to be nutritionally similar, in the sense that they represent uncultivated foods, to those eaten by our human ancestors.

New knowledge of both the nutrient composition and the physiological effects of AA plant foods therefore provides another perspective in the current debate on the composition of the 'prudent' diet and that of the diet on which humans evolved (the 'palaeolithic' diet). The purpose of this paper is firstly to describe the average composition of AA plants by food category, taking all the available data into account, and secondly to compare the averages with similar cultivated species. Our findings are relevant not only to readers with an interest in palaeolithic nutrition and human evolution, but to those involved in the development of dietary guidelines and the health of modern day traditional living AA.

\section{Which plants?}

The Australian bush contains thousands of edible wild plants, ranging from sweet and tangy fruits and starchy seeds to leaves, tubers, fungi and seaweeds. Early accounts of these plant foods can be found in the journals of European explorers, botanists. However, knowledge of their role in Aboriginal diets, especially in temperate Australia, is very incomplete. Extensive lists of plant and animal foods have been produced (Cleland, 1937, 1938; Irvine, 1957; Meggitt, 1957; Specht, 1958; Gould, 1969; Golson, 1971; Cribb \& Cribb, 1976; Levitt, 1981). However, the relative contribution of individual foods is difficult to determine from the records. For many years it was believed that the AA diet was predominantly vegetarian, particularly in the desert areas, but this view is no longer accepted. There is now strong evidence to show that AA diets in many areas were meat-oriented and there was a preference for meat, fat, honey and freshly harvested food (Lee, 1996). Plant foods were a supplement rather than an alternative to animal foods.

Of the plant foods listed, most appear to have been eaten infrequently, with only a few staples contributing significantly to the diet. In desert areas some plant species were important staples, but this desert existence may have been unnatural, the result of forced exile from their traditional lands. Nor did Aborigines eat everything that was edible. They had no cooking pots and did not boil foods, preferring to cook them in hot ashes. Most of the leaves consumed by early European settlers and convicts were considered inedible by AA (Low, 1991). Small cereals grains (seeds of the family Graminae) which have been staples for 'civilized' peoples since the Agricultural Revolution, made a surprisingly minor contribution to the diets of most hunter-gatherers (Eaton \& Konner, 1985). But archaeological evidence dating back to 15000 years ago indicates that some cereal grains (e.g. Panicum spp.) were important foods in grassland areas of Australia where river flooding was a regular occurrence. The wet-milling of grass seeds, compared with the dry-milling of tree seeds (such as acacias), is thought to have resulted in larger populations in grassland areas of Australia (Kirk, 1983).

\section{The nutritional composition of Australian Aboriginal plant foods}

Until recently, only fragmentary information on the nutritional composition of AA bushfoods was available. Since 1980, three major scientific centres in Australia (the Human Nutrition Unit 
at the University of Sydney, the School of Community Health at Curtin University of Technology in Perth and the Defence Science and Technology Organisation in Scottsdale, Tasmania) have systematically analysed a large number of plant and animal foods. Although each group worked independently and used different analytical methods, they collaborated to produce Tables of Composition of Australian Aboriginal Foods in 1993 (Brand Miller et al. 1993). The Tables include most of the known edible plant species from the north, west and central parts of Australia and form the basis of the present data analysis.

\section{Methods of collection and analysis}

Details of collection and methods of nutrient analysis have been described in the Tables (Brand Miller et al. 1993). Importantly, AA played an essential role in the collection and identification of the plants and their preparation and cooking. The species listed are therefore recognized as AA food resources. They may represent almost all or only a proportion of the species that were once exploited by AA on an Australia-wide basis. Apart from the methods for determining carbohydrate and fibre (discussed later), recommended methods of food analysis were used. The quality of the data was enhanced by the use of standard reference materials, recovery studies and duplicate analyses.

\section{Interpreting the nutrient data}

A number of points must be borne in mind in interpreting the composition of the wild plant foods. The values are based on raw or cooked food (as indicated) analysed on a wet weight basis. Hence small variations in water content due to state of desiccation will alter the content of nutrients correspondingly. The wild foods may appear to be more nutrient dense simply because they were collected in a climate that leads to rapid water loss.

Much of the data in the Tables represents the analysis of the whole item including parts that may not have been eaten or were chewed and then discarded. The acacia seeds, for example, have been analysed as whole seeds but in practice the hard seed coat was separated very effectively after grinding. This separation process required superb manual skills that AA women learned during childhood. In the laboratory, the hard seed coat was impossible to separate from the rest of the seed. The results of analysis on the whole seed therefore underestimate the protein, fat and carbohydrate content of the seeds as eaten.

Ideally, the values in food composition tables should be a true reflection of the usual composition of the food. Pooled multiple or representative samples from different sources and geographic locations should be analysed. But wild foods are difficult to obtain and may require a great deal of physical effort to prepare, resulting in only small single samples available at any one time. Each AA food was therefore analysed separately. One of the most reassuring aspects of preparing the Tables was the realization that many foods had multiple analyses (between 3 and 12) from different sources, making the data much more reliable as an indication of the average composition.

Most foods have a complete macronutrient analysis: water, protein, fat, ash and total carbohydrate (by difference), from which energy content can be calculated using the Atwater factors. Total carbohydrate includes sugars and starch and often dietary fibre. In some instances, dietary fibre was assayed separately and a figure for available carbohydrate (starch and sugars) was calculated. Using the latter figure in the energy calculation gives a truer 
estimate of the energy value of the food, particularly for very fibrous foods. However, it is likely that fibre has been underestimated and the available carbohydrate figure (starch plus sugars) is an overestimate in the great majority of foods. Values for the minerals $\mathrm{Na}, \mathrm{K}$ and $\mathrm{Ca}$ are available for most of the foods, and over half have information about other elements $(\mathrm{Mg}$, $\mathrm{Fe}, \mathrm{Zn}$ and $\mathrm{Cu}$ ). Unfortunately vitamin analyses are the most incomplete, with only some data for vitamin $\mathrm{C}$, thiamin and riboflavin.

The average nutrient composition of all the samples analysed in each food category (fruit, root, leaves etc) is shown in Table 1 (macronutrients) and Table 2 (micronutrients) together with the average composition of similar cultivated foods (Paul \& Southgate, 1978) as eaten in western countries today for comparison. Table 3 shows the average composition of all AA plant foods combined, irrespective of plant part. The findings in each food category are discussed separately below. Table 4 provides an estimate of the contribution of plant foods to nutrient intake according to the ratio of animal : plant foods.

\section{Fruits}

Primates evolved on a diet based on fruits and berries in the tropical rain forests of Africa 50 million years ago. Today, fruits are not usually regarded as food staples, but as useful source of micronutrients such as vitamin C. Dietary guidelines in several countries recommend two pieces of fruit a day, one being a citrus variety. In contrast, AA people in arid areas relied on some native fruits to a significant degree. The bush tomato, Solanum chippendalei, and similar Solanums were important desert staples. When ripe, the fruit are green with a yellow tinge and filled with poisonous black seeds which are discarded. During dry periods the bush tomato is preserved by natural dehydration. The AA of the Western Desert threaded the fruit on a thin stick, dried them in the sun, and then stored them indefinitely in tree caches (Cribb \& Cribb, 1974). The dried husks were dipped in water prior to eating to make them more palatable. Ripe S. chippendalei fruits contain appreciable amounts of carbohydrate (sugars plus starch, $17 \%$ and only $3 \%$ fibre) and a little protein (1-2\%). They were probably one of the most important sources of vitamin $\mathrm{C}$, containing $12-49 \mathrm{mg} / 100 \mathrm{~g}$. They are also a rich source of thiamin, containing $0.24 \mathrm{mg} / 100 \mathrm{~g}$, the recommended amount for adults being about $1.1 \mathrm{mg} / \mathrm{d}$.

Other important desert fruits include the raisins, Solanum centrale and S. ellipticum, which were eaten both fresh and in the naturally dehydrated state. The dried fruit was often ground between stones and mixed with water to a seedy paste and then compacted into balls as large as $25 \mathrm{~cm}$ (yes!) in diameter (Gould, 1969). The outer surface dried to a crust and in this state the fruit could be stored indefinitely. The average nutrient analysis of all the dried AA fruits in Table $1(\mathrm{n}=7)$ shows that they are high in carbohydrate $(59 \%, v .65 \%$ in cultivated sultanas and raisins), and contain moderate amounts of protein $(8 \%)$ and fat $(4 \%)$ depending on the state of desiccation. They appear to be good sources of vitamin C $(17 \mathrm{mg} / 100 \mathrm{~g})$, which is surprising because sultanas and raisins contain none, presumably as a result of the drying process.

Santalum fruits were also important staples of the AA of the Western Desert and were even more abundant after prolonged dry weather. Fruit of $S$. acuminatum (the quandong) is bright red at maturity with a firm fleshy layer surrounding the edible stone which 'rattles' when the fruit is ripe. They were one of the few AA foods to be readily adopted by the first Europeans in Australia. Their pithy flesh is a good source of carbohydrate (17\%, and only $4 \%$ fibre). The kernel is roasted prior to eating and is rich in fat $(63 \%)$ and energy $(2920 \mathrm{~kJ} / 100 \mathrm{~g})$. Rivett et al. (1985) have shown high amounts of a toxic fatty acid in the kernel oil. Attempts to cultivate the 
quandong have proved difficult. CSIRO scientists have studied the horticulture of the quandong with a view to commercial cultivation, but its symbiotic root habitat has so far resisted attempts to make it commercially viable (Grant \& Buttrose, 1978). S. lanceolatum, the bush plum, is smaller than the quandong and deep blue-black in colour with a sweet, agreeable taste. It was not a staple but during season it would have made a useful contribution to carbohydrate intake (23\%, and only $3 \%$ fibre) and vitamin C (16 mg/100 g).

The native fig, Ficus platypoda, is very productive in arid environments and was a favourite with some groups of AA (Sweeney, 1947). The samples analysed contain some protein $(3 \%)$ and fat $(2 \%)$ as well as extraordinary levels of $\mathrm{Mg}(1041 \mathrm{mg} / 100 \mathrm{~g})$. Wild oranges, Capparis spp., were also good sources of carbohydrate (17\% with $11 \%$ fibre) compared with most cultivated fruits (even when their lower water content is taken into account). $C$. spinosa fruits are orange-yellow and up to $7 \mathrm{~cm}$ in diameter at maturity. The flesh is sweet but spicy and contains numerous black seeds which are spat out after the flesh is sucked off. They contain high levels of vitamin $\mathrm{C}$ (up to $98 \mathrm{mg} / 100 \mathrm{~g}$ ) and one sample contained a very high amount of thiamin $(0.7 \mathrm{mg} / 100 \mathrm{~g})$. The desert banana (Leichhardtia australis) has a wide distribution throughout the drier parts of Australia. The fruits are shaped like pointed eggs about $4-10 \mathrm{~cm}$ long and $3 \mathrm{~cm}$ in diameter. Their taste has been compared to young peas, fresh and very crisp. AA usually roast the mature pods. The protein content is relatively high (4\%). They contribute a little vitamin $C(5 \mathrm{mg} / 100 \mathrm{~g})$ and one sample contained very high levels of thiamin $(2.9 \mathrm{mg} / 100 \mathrm{~g})$. The leaves of $L$. australis were also eaten.

The average nutrient composition of all the fruit samples analysed $(n=334)$ is shown in Table 1 (macronutrients) and Table 2 (micronutrients). On first inspection they appear to be a little higher in protein $(2 v .1 \%)$ and fat $(1 v .0 \%)$ compared with the average of 17 types of cultivated western fruits. These small differences could be explained in large part by the lower water content of the wild foods ( $72 v .85 \%$ in cultivated foods). Native fruits also appear to be twice as high in both carbohydrate $(21 v .9 \%)$ and fibre $(8 v .3 \%)$. However, because the methods used are not ideal (see above), the carbohydrate is probably an overestimate and the fibre an underestimate. One thing is certain, however: wild fruits would have given people a much higher fibre intake than we presently obtain from modern fruit varieties. If AA people ate half their plant food in the form of fruit (about $180 \mathrm{~g}$ fruit for a $12500 \mathrm{~kJ}$ ( $3000 \mathrm{kcal}$ ) diet with $20 \%$ energy as plant food), and we use the underestimate of $11 \%$ fibre, they would ingest about $20 \mathrm{~g}$ fibre/d from this source alone.

The average $( \pm S D)$ vitamin C content of AA fruits is $152 \pm 650 \mathrm{mg} / 100 \mathrm{~g}(\mathrm{n}=220)$ but this calculation is markedly affected by the inclusion of Terminalia ferdinandiana, the world's highest plant source of vitamin C (Brand et al. 1982). Excluding $T$. ferdinandiana (the green plum), the mean ( \pm SD) is only $25 \pm 82 \mathrm{mg} / 100 \mathrm{~g}(\mathrm{n}=207)$, similar to the $27 \mathrm{mg} / 100 \mathrm{~g}$ calculated by Eaton \& Konner (1985). This is lower than the average vitamin $C$ in cultivated fruits (34 mg/100 g, Table 5).

\section{Roots and tubers}

Aboriginal people ate many kinds of roots, tubers and bulbs. The ones that stand out are the Dioscorea species (yams), and Ipomoea costata (wild potato), Cyperus species (native onion) the yam daisy, Microseris scapigeris. Many of the roots contained a poison which was removed by extensive leaching in running water. Some have a composition which is similar to a potato with about $15-20 \%$ carbohydrate, but others are more like a carrot with much less carbohydrate and less energy, but lots of fibre. Many roots and tubers (for example Microseris 


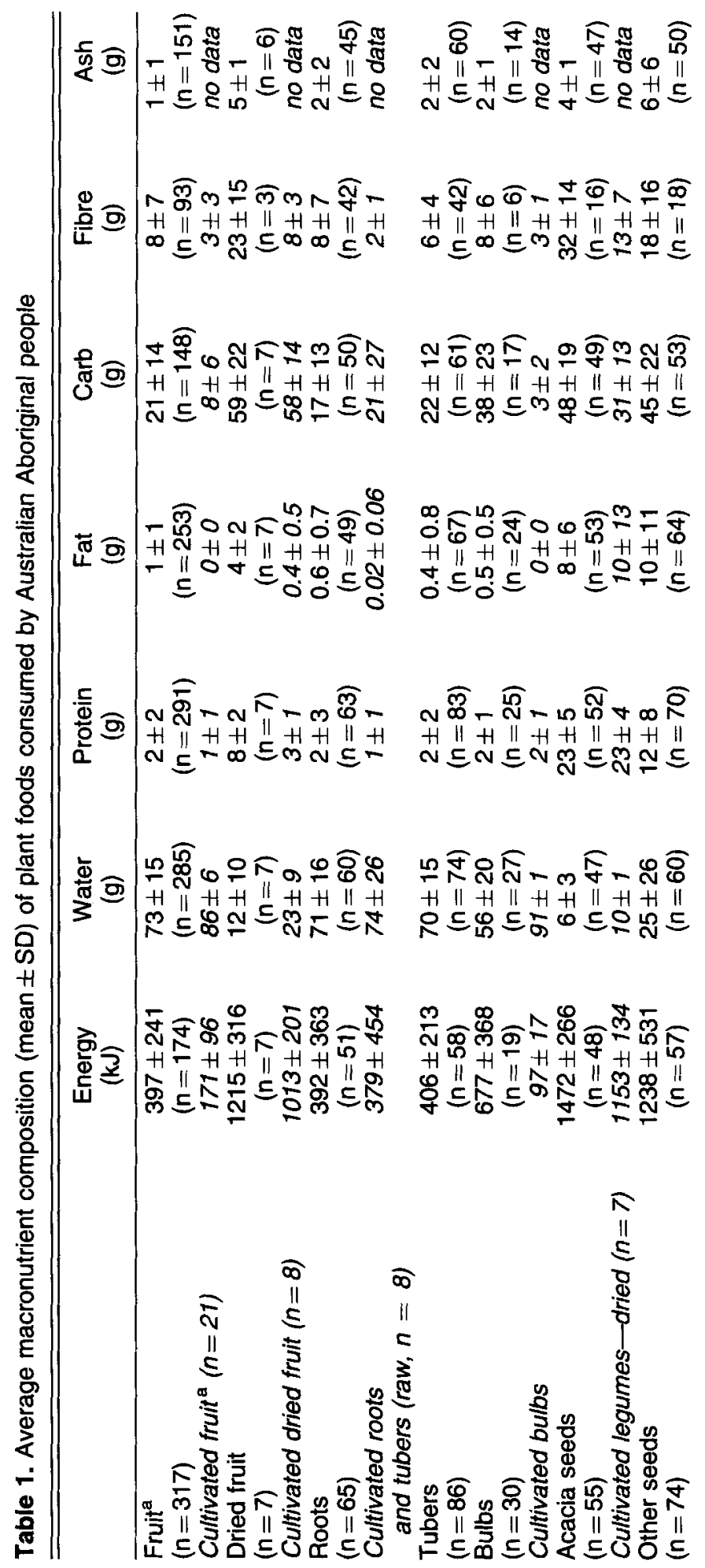




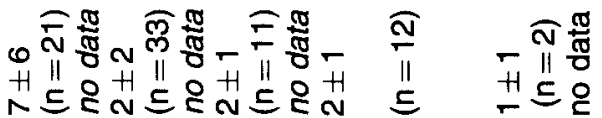

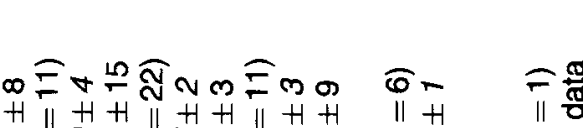

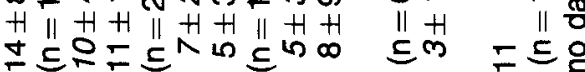

艼范

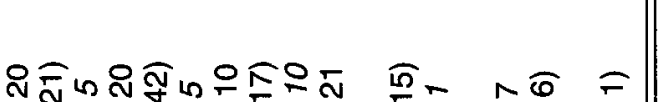

$H\|H+H\| H+H+H$ \|

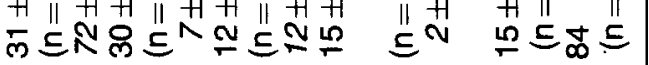

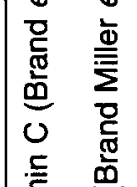

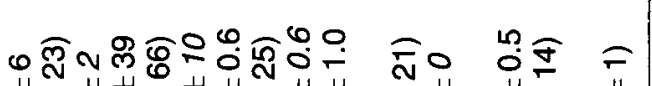

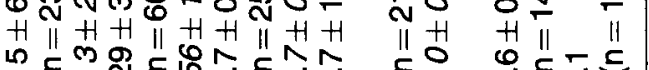

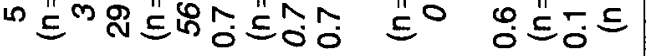

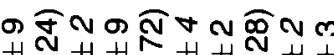

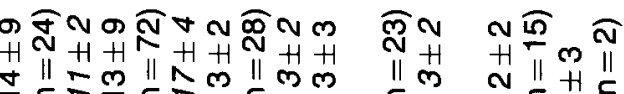

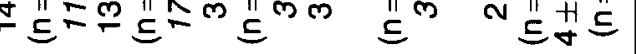

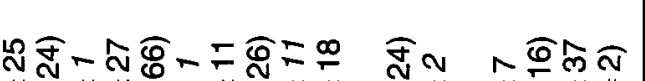

$H\|H+H+H\|+H$ \|H H $\|+H\|$

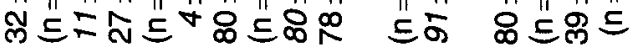

요

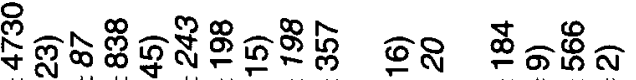
$H \| H+$ II $H+H$ II $H+H \quad H$ II H II

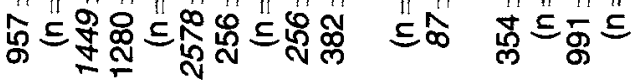

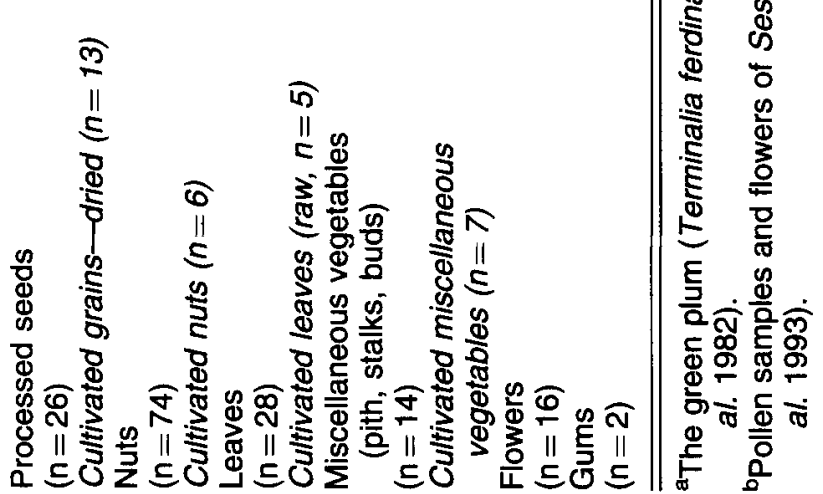




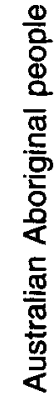

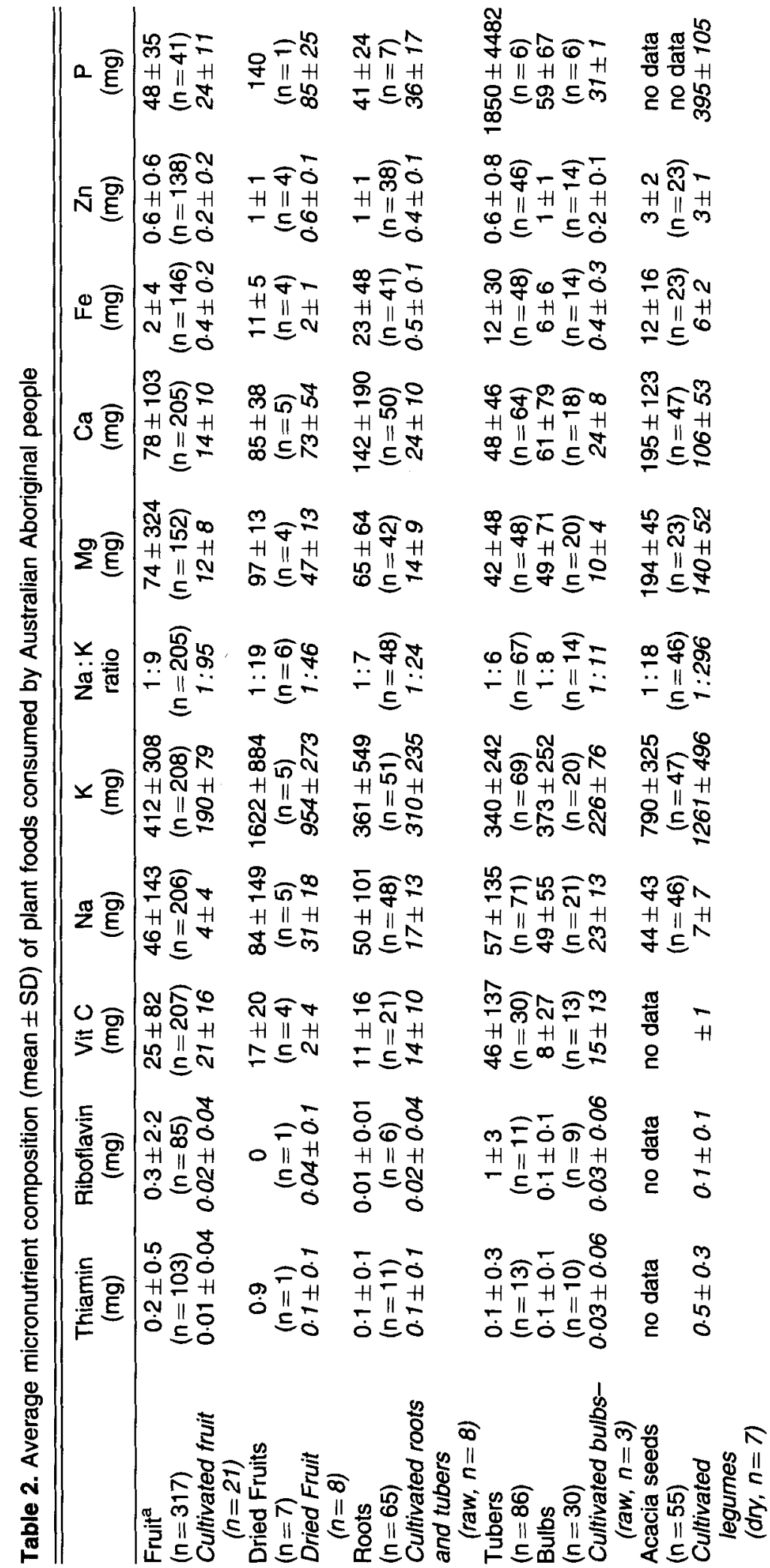




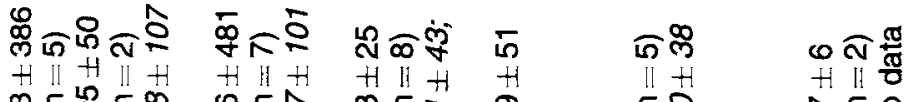

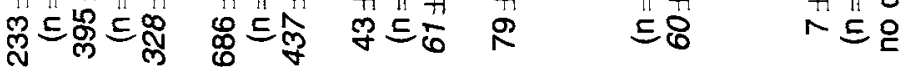

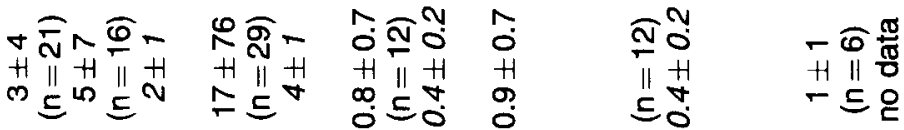

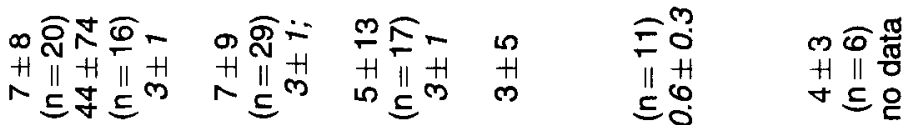

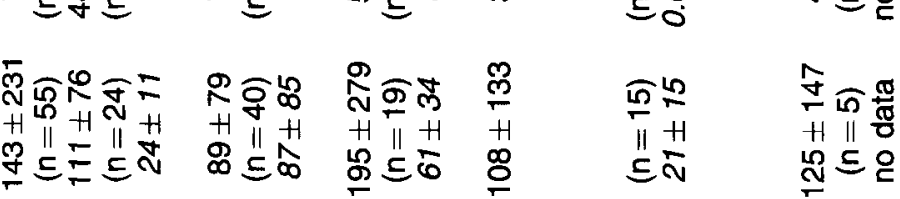

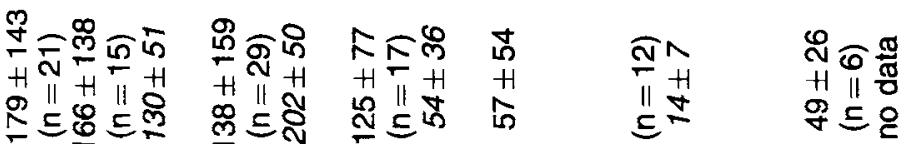

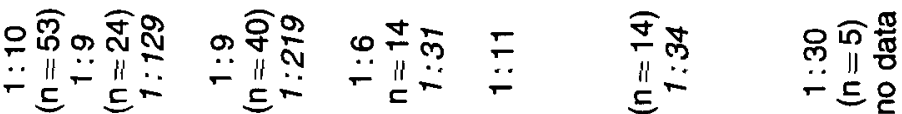

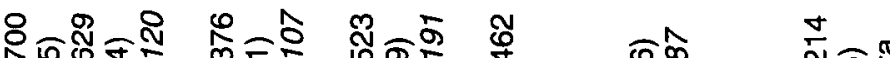

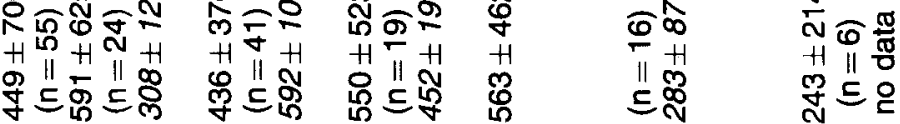

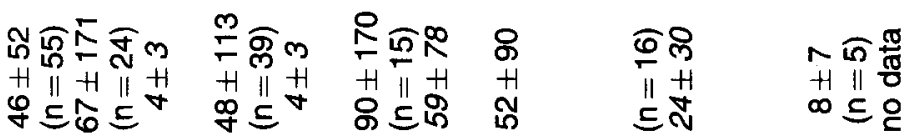

돔

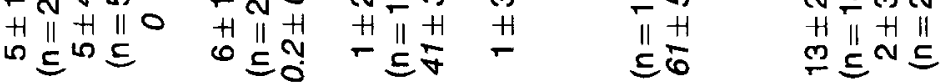

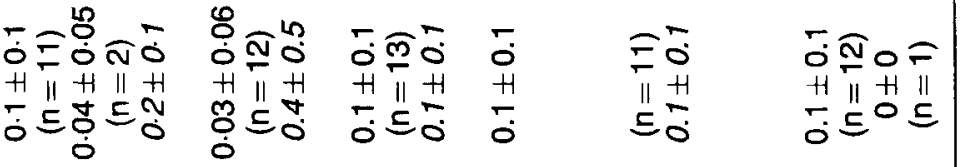

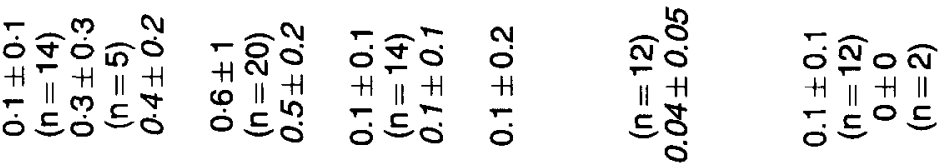

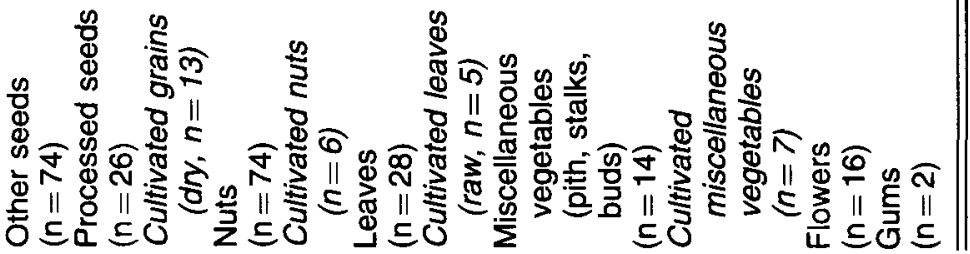


Table 3. Average nutritional values (mean $\pm S D$ ) of 829 wild vegetable foods consumed by Australian Aboriginals

a. Macronutrients

\begin{tabular}{lcc}
\hline \hline Content/100 $\mathrm{g}$ & Nutritional value \\
\hline Energy (kJ) & $700 \pm 580$ \\
Water (g) & $58 \pm 29$ \\
Protein (g) & $6 \pm 8$ \\
Fat (g) & $5 \pm 15$ \\
Carbohydrate (g) & $28 \pm 21$ \\
Fibre (g) & $11 \pm 11$ \\
Ash (g) & $2.5 \pm 3 \cdot 2$ \\
\hline \hline
\end{tabular}

b. Micronutrients

\begin{tabular}{lc}
\hline \hline Content/100g & Nutritional value \\
\hline Thiamin $(\mathrm{mg})$ & $0.2 \pm 0.6$ \\
Riboflavin $(\mathrm{mg})$ & $0.2 \pm 1.5$ \\
Vitamin C (mg) & $25 \pm 82^{\mathrm{a}}$ \\
Na (mg) & $48 \pm 118$ \\
$\mathrm{~K}(\mathrm{mg})$ & $426 \pm 459$ \\
$\mathrm{Na}: \mathrm{K}$ ratio & $1: 9$ \\
$\mathrm{Mg}(\mathrm{mg})$ & $87 \pm 213$ \\
Ca $(\mathrm{mg})$ & $104 \pm 142$ \\
Fe (mg) & $15 \pm 33$ \\
Zn (mg) & $4 \pm 24$ \\
$\mathrm{P}(\mathrm{mg})$ & $112 \pm 230$ \\
\hline
\end{tabular}

a The green plum (Terminalia ferdinandiana) was excluded from the analysis because of its exceptionally high content of vitamin C (Brand et al. 1982).

scapigeris) contained an unabsorbable carbohydrate called inulin which is thought to promote a healthy intestinal flora (Incoll et al. 1989). In the Tables we are unable to distinguish between the roots that were high in inulin and those high in starch.

In the Central Desert the tubers of Ipomoea costata and Vigna lanceolata and the bulbs of Cyperus bulbosus were important staples available during any season with suitable rainfall and thereafter they are preserved underground indefinitely (O'Connell et al. 1983). Sweeney (1947) writes of the desert yam as "the most remarkable of the native foods that nature has developed in the desert providing a nutritious food under hard conditions which can be harvested at any time of the year". Sweeney's desert yam was probably Ipomoea costata, not Dioscorea sp. as

Table 4. Estimated nutritional contribution from plant foods for various subsistence patterns ranging from 20 to $80 \%$ energy as plant foods

\begin{tabular}{lrrrr}
\hline & $20 \%$ plant & $40 \%$ plant & $65 \%$ plant & $80 \%$ plant \\
\hline Weight of plant foods eaten $(\mathrm{g})$ & 360 & 720 & 1170 & 1440 \\
Protein $(\mathrm{g})$ & 22 & 44 & 72 & 88 \\
Fat $(\mathrm{g})$ & 18 & 36 & 59 & 72 \\
Carbohydrate $(\mathrm{g})$ & 101 & 202 & 328 & 404 \\
Fibre $(\mathrm{g})$ & 40 & 80 & 130 & 160 \\
Vitamin C (mg) & 90 & 180 & 293 & 360 \\
\hline \hline
\end{tabular}


was originally thought (Meggitt, 1957). The tubers are found 50 to $100 \mathrm{~cm}$ underground and are harvested by digging with yam sticks and using wooden food vessels as shovels. Tubers of $I$. costata up to the size of a human head were once obtained. They can be eaten raw or cooked and have a slightly sweet taste.

The average nutrient composition of all the AA roots $(n=65)$, tubers $(n=86)$ and bulbs $(\mathrm{n}=30)$ is shown in Tables 1 and 2 . Compared with 11 cultivated rootstocks, AA roots and tubers are slightly lower in water $(76 v .70 \%)$ but fairly similar in protein $(1.6 v .2 \%)$ and fat $(0$ v. $0.5 \%$ ). The AA rootstocks are apparently similar in carbohydrate (17-22\%) to cultivated varieties $(19 \%)$, but the figure for AA is a likely overestimate. The fibre content of AA roots and tubers is at least $8 \%$ (an underestimate) compared with only $2 \%$ in the cultivated bulbs such as onions and leeks. AA bulbs $(\mathrm{n}=30)$ are more desiccated (average moisture $56 \% v$. $90 \%$ in cultivated bulbs) and significantly higher in carbohydrate compared with cultivated foods $(3 v .5 \%)$. The vitamin $\mathrm{C}$ content of AA roots and bulbs averages only $8-11 \mathrm{mg} / 100 \mathrm{~g}$, while the tubers are a much better source with $46 \mathrm{mg} / 100 \mathrm{~g}$, although the variation is very high. The thiamin and riboflavin content of the wild and cultivated varieties is similar.

\section{Nuts}

Some nuts were heavily exploited such as the Pandanus nut in Arnhem land, which was high in energy because of its fat content $(47 \%)$. The bunya bunya tree (Araucaria bidwillii) of southwest Queensland bears fruit once in three years and the nuts were so relished that AA people travelled long distances to eat them and congregated with other tribes for several weeks at a time. They were good sources of protein $(11 \%)$ and carbohydrate $(40 \%)$.

The average composition of AA nuts $(n=74)$ is very different from that of the cultivated varieties ( $n=9$, including peanuts which strictly speaking are not nuts). The fat content of AA nuts averages $29 \%$ while that of cultivated nuts averages $59 \%$. The carbohydrate content of AA nuts is four times higher $(30 \%)$ than that of cultivated species $(7 \%)$. The average protein content of AA nuts is similar to that of the cultivated species (average $13 v .17 \%$ ), in fact about the same as that in walnuts $(14 \%)$. Fibre content is also similar (11\% v. $7 \%$ respectively). AA nuts are rich sources of thiamin $(0.6 \mathrm{mg} / 100 \mathrm{~g})$ but not riboflavin or vitamin $\mathrm{C}$.

\section{Seeds}

Although seeds, particularly cereals (seeds of the family Graminae) are thought to have played only a minor role in palaeolithic diets, they appeared to be important in the diet of at least some groups of AA. Before European occupation, collection of seeds was widespread, particularly in arid areas. It was predominant in the grassland areas of Australia but also in the desert areas where acacia trees (wattle trees) yielded abundant seeds. Grindstones used for seed grinding have been found in many areas. The seeds were excellent sources of energy, high in protein and often fat too, and vitamins and minerals. But they were also high in fibre and not all the nutrients would have been fully absorbed.

\section{Acacia seeds}

It appears that $\sim 50$ of the 800 species of Acacia (wattle trees) native to Australia were used by AA for food. Despite the wattle being Australia's national flower, the seeds are generally 
unknown to non-AA as food sources. But Acacia seeds are outstanding in their nutrient content, being much higher in energy, protein and fat than any cereal crop such as wheat and rice. Their composition more closely resembles that of the legume family to which the Acacias actually belong.

The protein content of dried acacia seeds is high, averaging (mean $\pm \mathrm{SD}$ ) $23 \pm 5 \%$ with a range of 11 to $45 \%$. Some legumes, such as soyabeans have even higher amounts, but $100 \mathrm{~g}$ of acacia seed could provide about $40-50 \%$ of the recommended dietary allowance for protein. Protein content was calculated by multiplying the nitrogen content by the factor 6.25 . Whether this factor is appropriate for acacias is not known because the amino acid proportions have not been studied in detail (Pettigrew \& Watson, 1975; Murray et al. 1978). Although some nitrogen may be present as non-protein nitrogen, this is not likely to limit the value of acacias as a good source of amino acids and non-specific nitrogen needed for growth and maintenance. If acacias are similar to other legumes, the limiting amino acid will be methionine.

The fat content of acacia seeds is higher than most legumes, averaging $8-9 \%$, but varies more than the protein. It ranges from about 2 to $28 \%$. Fat content influences the calculated energy content considerably. The oil extracts of some of the acacias, particularly $A$. coriacea and $A$. tenuissima are extremely palatable products and commercial exploitation is feasible because the oil seed content is high. Brown (1985) undertook a comprehensive analysis of the fatty acids in 19 edible acacias. The seed oils generally exhibited a high proportion of linoleic acid $(40-70 \%)$, oleic (13-34\%) and palmitic (7-16\%). The ratio of polyunsaturated to saturated fatty acids (P:S ratio) was high, greater than $1: 1$ in most cases and greater than $4: 1$ in some species. Others have found similar results (Rivett et al. 1971). Six species were different in that they contained higher proportions of oleic acid (38-56\%), similar to olive oil. These monounsaturated species were A. adsurgens, A. coriacea, A. cowleana, A. crassicarpa, A. ligulata and A. tetragonophylla.

Brown (1985) found that the arils attached to the majority of seeds contributed a major proportion of the total seed oil, depending on their size, ranging from 5 to $76 \%$ on a dry weight basis. There was a good correlation between the fatty acid composition and aril colour. Those with bright arils (yellow, orange, red) had a lower percentage of linoleic and a higher proportion of oleic and palmitic, with the converse in seeds with a dull aril. The unsaturated nature of the acacia oils means that they are desirable from a health point of view, but their potential to oxidize may present problems in food processing and storage, unless they are protected by adequate antioxidants.

The mean $( \pm S D)$ total carbohydrate (starch + sugars + dietary fibre) content of acacias is $56 \pm 14 \%$. This is lower than the total carbohydrate content of lentils, but higher than that of soyabeans (Paul \& Southgate, 1978). The amount of available carbohydrate (starch + sugars) in acacias can be estimated in those samples where fibre was determined $(n=17)$. The average is $26 \%$ but ranges from about 4 to $50 \%$. These estimates are probably too low. More reliable estimates of available carbohydrate were made by Thorburn et al. (1987a) who analysed starch and sugars directly in the wet pastes made from three acacia species (the seed coat had been removed). The starch content varied from 30 to $38 \%$ with little sugars $(<2 \%)$.

Fibre analyses were made on only 17 of the 58 samples, using a number of different methods, none of them ideal. The fibre content varied from 4 to $63 \%$ with a mean of $32 \%$. However, these values could be overestimates because some of the starch may have analysed as fibre. Certainly, the average figure is higher than that of published values (Paul \& Southgate, 1978 ) for other raw whole legumes such as lentils (11-12\%). Energy content is high in all the acacias, averaging $( \pm S D) 1480 \pm 270 \mathrm{~kJ}$ per $100 \mathrm{~g}$. The values are greater than many other legumes because the acacias contain more fat. 
Three species of Australian acacias, $A$. colei (which formerly included A. holosericea), A. cowleana and $A$. tumida are presently being tested in sub-Saharan Africa as a prelude to their incorporation into local diets or to serve as famine food (Harwood, 1994). The Australian Centre of International Agricultural Research (ACIAR) has sponsored a project to carry out a detailed nutritional and safety evaluation of the seeds. Amino acid analysis indicated that tryptophan was the first limiting amino acid in $A$. colei although rats fed A. colei-based diets showed better growth when $A$. cole $i$ was supplemented with methionine. Human trials in which $A$. cole $i$ has been incorporated at the level of $25 \%$ energy intake are currently in progress.

\section{Other seeds}

Portulaca oleracea, the pigweed utilized by the AA, is botanically different from the common garden pigweed. Dr. Joseph Bancroft, an eminent natural scientist and medical man of the nineteenth century, called $P$. oleracea "perhaps the most valuable of all specimens of native food under examination" (Cribb \& Cribb, 1974). They are indeed exceptionally nutritious with close to $20 \%$ protein and $16 \%$ fat content, but the dietary fibre content is high $(14 \%$ in the damper). The flavour of the tiny black seeds resembles linseed.

Other important grass seeds such as Fimbristylis spp., Calandrinia balonnensis, Chenopodium rhadinostachyum, Eragrostis eriopoda and Panicum australiense are similarly high in protein (range 14-20\%) but the fat content and therefore energy varies among the species (range $2-21 \%$ ).

The average $( \pm S D)$ protein content of seeds other than acacias is $12 \pm 8 \%$, while fat averages $10 \Omega 11 \%$. In cultivated cereals, protein content averages $11 \%$, while fat is usually less than $3 \%$. In this regard, the AA seeds more closely resemble oats which have a fat content of around $8 \%$. The AA seeds have less carbohydrate $(45 \% v .72 \%)$ and more fibre $(18 \% v$. $10 \%$ ) than cultivated cereals. Calcium content is also worth mentioning. The average Ca in AA seeds is $143 \pm 231 \mathrm{mg} / 100 \mathrm{~g}$ compared with $24 \pm 11 \mathrm{mg} / 100 \mathrm{~g}$ in cultivated species.

\section{Processed seeds}

Some of the AA foods had been processed in traditional ways prior to analysis. In this form they contain $14 \%$ protein, $5 \%$ fat, $31 \%$ carbohydrate and $14 \%$ fibre. It is clear that while processing removed some of the nutrients, substantial amounts remained and this includes a great deal more fibre and less carbohydrate than usually found in modern processed cereals.

\section{Leaves and miscellaneous vegetables}

This category included the leaves, leaf buds, pith and stalks of various plants. As a group they played a fairly minor role in AA diets. Their nutrient content is characterized by the high moisture content $(80 \%)$, a small amount of protein $(3-4 \%)$ and very small amounts of fat $(<1 \%)$. Carbohydrate and fibre averaged $12 \%$ and $5 \%$ respectively in the leaves and $16 \%$ and $10 \%$ in other parts of the plant. However, it is highly likely that much of the carbohydrate is in fact non-starch polysaccharide. This food category was not a good source of vitamin C, averaging only $0-2 \mathrm{mg} / 100 \mathrm{~g}$. Cultivated leaves are a useful source of vitamin $\mathrm{C}$, averaging $34 \pm 33 \mathrm{mg} / 100 \mathrm{~g}$. However, the highly perishable nature of leafy vegetables means that any 
vitamin $\mathrm{C}$ present may have been easily oxidized during transit of the wild foods to the laboratory. Cultivated leaves such as spinach and lettuce are higher in moisture (93\%), similar in protein $(2-3 \%)$, but much lower in carbohydrate and fibre $(<1 \%$ and $3 \%$ respectively). Once again, there is marked contrast between the cultivated and wild species in respect of fibre content.

\section{Flowers}

Flowers do not feature to any significant extent in western diets, but there were quite a few flower parts collected as part of these studies. This includes the pollen and nectars. They were a useful source of vitamin $C$, the mean \pm SD being $19 \pm 29 \mathrm{mg} / 100 \mathrm{~g}$.

\section{Beverages}

AA beverages included coconut milk, diluted nectars and water. Canthium latifolium berries when washed imparted a sweet flavour to the wash water. Plants with water storage properties were also utilized. Kurrajong roots (Brachychiton gregorii) and the desert yam (Ipomoea costata) were chewed and sucked. AA made mildly sweet, unfermented beverages by steeping flowers and other plant parts in water. Hakea spp., Acacia spp., mistletoe (Loranthus and Amyema spp.) and Leichhardtia australis were used for this purpose. Some AA also made a drink from the mashed seed aril (cap) of Acacia coriacea. Coconut milk was a rich source of nourishment but most other beverages contributed little more than water and a little vitamin $\mathrm{C}$ $(5 \mathrm{mg} / 100 \mathrm{~g})$. High water intake may have been particularly important in a diet that contained large amounts of fibre. In arid areas during the dry season, it may have been available in limited quantities. However, AA managed their water resources carefully and it is unlikely to have been a limiting factor in food intake.

\section{Mineral content}

In general the Australian native plants are richer sources of minerals such as $\mathrm{Ca}$ and trace elements such as $\mathrm{Fe}, \mathrm{Zn}$ and $\mathrm{Cu}$ than similar cultivated plants. The levels in some plants are outstanding for example, a mixture of Portulaca oleracea/P. interterranea seeds had $275 \mathrm{mg} /$ $100 \mathrm{~g}$ Fe (about 20-30 times the recommended daily requirement), a value that requires confirmation. Acacia seeds, in common with other legumes, were a rich source of inorganic micronutrients. A $100 \mathrm{~g}$ serving contributes about $20 \%, 66 \%$ and $20 \%$ of the female recommended dietary allowance for $\mathrm{Ca}, \mathrm{Fe}$ and $\mathrm{Zn}$ respectively. Mineral availability is reduced in plants containing fibre and associated factors such as phytate, which bind calcium, iron and zinc and make them less available for absorption.

\section{Toxic components}

Seeds, nuts and rootstocks often contain toxic compounds and antinutritional factors such as proteinase inhibitors, amylase inhibitors and haemagglutinins which are denatured by heat. Undenatured forms interfere with intestinal absorption of nutrients and produce growth retar- 
dation (Liener, 1979). Generally these antinutrients are destroyed by cooking and do not cause pathological symptoms. However, other toxic components are not affected by heat, e.g. tannins, toxic amino acids, cyanogenetic glycosides and alkaloids, and may induce adverse consequences if consumed in large amounts (Jelliffe \& Jelliffe, 1982).

Some of the AA seeds may contain toxic amino acids, including djekolic acid derivatives and lathyrogens, although there have been no reports of drowsiness, renal failure or muscle paralysis in AA who relied upon the seeds as food. Presumably the levels of these toxins are low and do not present a problem as part of a mixed diet. Only a few species of acacia seeds contain haemagglutinin activity and there are no reports of amylase inhibitors (Toms et al. 1971). However, all acacia species examined by Kortt (1982) showed antitryptic and antichymotryptic activity (i.e. they inhibit the proteinase enzymes in the stomach). The inhibitor is similar to soyabean trypsin inhibitor. The levels of activity varied widely (0.3-16.5 mg trypsin inhibited/g seed meal) between species and were generally in the lower range found in common food legumes such as peas and beans.

\section{Bushfoods: are they protective against the diseases of affluence?}

During this century the urbanization of AA has been associated with a dramatic rise in the prevalence of adult obesity, coronary heart disease and non-insulin dependent diabetes mellitus (NIDDM). AA plant foods are likely to have been 'protective' foods in the traditional way of life by way of providing adequate fibre, carbohydrate, micronutrients, antioxidants and other phytochemicals associated with fruits and vegetables. The need for some dietary carbohydrate to supplement endogenous synthesis, especially during pregnancy and lactation, may have been one of the main reasons that sweet plant foods (as well as bush honey) were actively sought. Animal foods provided protein and fat only. Plants also boosted physical activity because they needed to be gathered and prepared rather than simply purchased in a packet.

Insulin resistance is now known to underlie the development of obesity, coronary heart disease and NIDDM. Severe insulin resistance and subsequently NIDDM develops when genetically susceptible individuals are exposed to trigger factors, particularly visceral adiposity, unknown dietary components and reduced physical activity. Currently, up to $20 \%$ of urbanized AA and Pacific Islander populations develop NIDDM compared with $3 \%$ of Caucasians of European descent (Zimmet et al. 1982). It is plausible that the traditional diet and lifestyle helped to limit the development of insulin resistance by providing limited carbohydrate and adequate physical activity. Recent large scale prospective studies have suggested that the glycaemic index (GI) of the diet (or glycaemic load, which is a measure of the insulin demand generated by foods) plays an important role in the aetiology of NIDDM (Salmeron et al. $1997 a, b)$.

The main carbohydrate foods in western diets, such as bread, wheat flour products and potatoes, are largely of high GI, i.e. the carbohydrate is digested quickly and the blood glucose response shows a rapid and often sustained rise. Dramatic rises in blood glucose and a higher blood insulin profile throughout the day may stress $\beta$-cell function in a way that eventually leads to $\beta$-cell failure and the expression of diabetes. In contrast, legumes and unprocessed seeds have a low GI. In 1985, we hypothesized that one of the contributing factors to the rising NIDDM in AA was a change in the nature of the carbohydrate in the diet, i.e. from low to high GI (Thorburn et al. 1987a).

In our first study (Thorburn et al. 1987a) of 30 traditional AA and Pacific Islander foods, 23 were digested in vitro significantly more slowly than the starch in any of the seven western 
starchy staples $(P<0.05)$. Studies in vivo in healthy Caucasian subjects confirmed that the slowly digested foods also gave low glycaemic and insulin responses (Thorburn et al. 1987a). Differences in nutrient composition, cooking methods or $\alpha$-amylase inhibitors could not explain the differences between the traditional and western foods. Further experiments suggested that an inherent difference in the nature of the starch, i.e. the amylose: amylopectin ratio, was responsible. Bushfoods appeared to be higher in amylose and lower in amylopectin than western foods. Amylopectin starch is much more easily gelatinized and therefore digested and absorbed compared with amylose. We also found that lean healthy young AA produced much larger glycaemic and insulin responses after consumption of quickly digested starches than was observed in Caucasians (Thorburn et al. 1987b). This suggested that the western diet could produce an inordinately high demand for insulin that may on a chronic basis exhaust the insulin-secretory capacity of the $\beta$-cells. AA are probably therefore better adapted to the carbohydrate in their traditional plant foods.

\section{Other health implications}

It is often assumed that wild plants are richer sources of particular nutrients than similar cultivated plants. Our calculations show this to be true in many respects-the fruits and seeds particularly are richer sources of protein, fat, carbohydrate and some micronutrients. Some of these differences, however, can be explained by the lower moisture content. Plants alone would have contributed almost all the carbohydrate and fibre in the diet and much of the vitamin $\mathrm{C}$ (although liver and other animal organs eaten soon after death would also have contributed vitamin C).

The average nutrient composition of all the AA plant foods combined is shown in Table 3. These figures enable us to calculate the absolute contribution of plant foods to total food and nutrient intake as shown in Table 4 . We have assumed that the average physically active person needed to consume $12500 \mathrm{~kJ}$ or $3000 \mathrm{kcal} / \mathrm{d}$ from food. If AA derived $20-40 \%$ of their food energy from plants (the most likely range), they ate between 360 and $720 \mathrm{~g}$ fruit and vegetables each day. At the other extreme, if the ratio of plant to animal food was $80: 20$, they ate $1.4 \mathrm{~kg}$ plant food/d, such a large amount that it seems unlikely to have been the case. Much of each day would have been devoted to the simple act of eating.

Our calculations also show that AA would have eaten only 101-202 g carbohydrate/d when $20-40 \%$ of energy was derived from plant foods. These figures would be regarded as too low according to current dietary guidelines in western countries, which promote a high carbohydrate intake $(300-350 \mathrm{~g} / \mathrm{d})$ at the expense of saturated fats. However, proportionately more of AA dietary energy would have been derived from animal protein rather than animal fats. Thus the ratio of carbohydrate : fat : protein energy may have been around $25: 25: 50$, i.e. very different from recommendations in many western countries today of $55: 30: 15$.

The traditional AA diet was also believed to be generally low in sugars (Lee, 1996), although sweetness would have been provided by fruits (especially dried fruits), native honey, honey ants, blossoms and gums. AA are described as having an exceptional 'sweet tooth' and many early observers commented on the dietary preference for sweet foods. The enthusiastic pursuit of honey was said to be out of proportion to the small quantities obtained (Lee, 1996). If plants contributed only $20 \%$ of energy intake, fruit is likely to have contributed at least half of this, mostly in the form of sugars. Honey, honey ants and gums might have contributed another $2-5 \%$ to energy intake. Thus, up to $15 \%$ of energy may have been derived from sugars. This is close to that consumed by many western nations today- $18 \%$ energy from all sugars including 
naturally occurring and refined sugars. The AA figure is much higher if we assume that plants contributed more than $20 \%$ of energy. Given these conservative calculations and the fact that AA adored sweetness, we believe it is not correct to assume that AA diets were low in sugars.

Pauling (1975) argued that our primate ancestors ate the equivalent of $4 \mathrm{~g}$ vitamin $\mathrm{C} / \mathrm{d}$ but there is no evidence that AA routinely ate such large quantities. AA foods are not higher sources of vitamin $\mathrm{C}$ than cultivated foods today $(25 \mathrm{mg} v .34 \mathrm{mg} / 100 \mathrm{~g}$ respectively). If $20 \%$ energy was derived from plant foods, they ingested $90 \mathrm{~g} / \mathrm{d}$ vitamin $\mathrm{C}$, not unlike the levels of consumption that we see today. If they lived along the north-west coast of Australia and liked the lip-pursing flavour of the green plum ( $T$. ferdinandiana) they might have eaten up to $5000 \mathrm{mg} / \mathrm{d}$ when the fruit was in season.

It is clear that AA plants were a rich source of dietary fibre (average $11 \%$ ) and the figures are likely to be underestimates. If AA consumed $20 \%$ energy as plant foods, they ingested about $40 \mathrm{~g}$ fibre/d. Most western populations consume $15-20 \mathrm{~g}$ fibre/d and authorities recommend that this be increased to $30-40 \mathrm{~g} / \mathrm{d}$. Fibre is thought to play a role in maintaining the health of the colon and preventing large bowel cancer, although the evidence for the latter is conflicting. Viscous fibre is known to have desirable effects on glucose and lipid metabolism while insoluble fibre increases stool water content and prevents constipation. It is interesting that AA would have achieved the recommended amount of fibre even though plants played only a supplementary role in the diet.

If $\mathrm{AA}$ ate $80 \%$ energy as plants (i.e. the highest proportion of energy eaten as plant foods amongst modern hunter-gatherer societies), then fibre intake may have been $160 \mathrm{~g} / \mathrm{d}$. What are the implications of such a high intake? The effect on absorption of macro- and micronutrients is likely to be detrimental. Agriculture markedly altered human nutritional patterns, reducing meat intake and increasing the proportion of plant foods. This shift had prominent morphological consequences including stunting of height and skeletal evidence of suboptimal nutrition (Eaton \& Konner, 1985). AA did not practise agriculture, although they did modify the environment to increase food production by innovative methods (i.e. 'fire stick' farming) and the germination of many favoured plants was assisted by regular burning of discrete areas of land. There is archaeological evidence that the height of AA skeletons also declined over the last 8000 years, but climatic changes, not agriculture, are thought to be responsible. The warming of the earth during this time was associated with a rise in the sea level which flooded many coastal habitats. Changes in rainfall patterns and plant and animal growth obviously affected human growth as well. But why and how is not known.

\section{Palaeolithic nutrition}

In the classic paper on palaeolithic nutrition by Eaton \& Konner (1985), the nutritional content of 44 vegetable foods most commonly eaten by six modern stone-age peoples (!Kung, _Kade, San and Hadza in Africa, Aborigines in Australia and Tasaday in the Philippines) was used as the basis of the average nutrient intake from plant foods of palaeolithic human beings. Eaton \& Konner reasoned that the nutrients may have varied between particular foods and varied with ambient conditions, but that the average nutrient values should reflect "central tendencies transcending these effects".

On the basis of the nutrient composition of those 44 vegetable foods and the assumption that $65 \%$ of energy was derived from plants (the mean value for 58 primitive societies), they estimated that plant foods would yield $60 \mathrm{~g}$ protein, $42 \mathrm{~g}$ fat ( $16 \mathrm{~g}$ polyunsaturated), $334 \mathrm{~g}$ carbohydrate, and $46 \mathrm{~g}$ fibre, $150 \mathrm{mg}$ sodium, $1500 \mathrm{mg}$ calcium. Average vitamin $\mathrm{C}$ intake was 
calculated to have been $393 \mathrm{mg} / \mathrm{d}$ and average fibre intake would be $46 \mathrm{~g} / \mathrm{d}$. Virtually all of the carbohydrate, vitamin $\mathrm{C}$ and all of the fibre eaten would have come from plants.

At least as far as AA are concerned, we now have a much wider range of nutrient data on which to base estimates of what might have been the contribution of plant foods to nutrient intake in Paleolithic times. If we compare our figures with those of Eaton \& Konner (1985) for diets providing $65 \%$ energy as plant, we get a fairly similar picture. AA would have eaten about $1.2 \mathrm{~kg}$ plant food $/ \mathrm{d}$ (rather than $1.5 \mathrm{~kg}$ ), more vegetable protein $(72 \mathrm{v} .60 \mathrm{~g}$ ), more vegetable fat $(59 v .42 \mathrm{~g})$, about the same amount of carbohydrate (334v. $328 \mathrm{~g})$, much more fibre $(130 v .46 \mathrm{~g})$ and less vitamin C (293v. $393 \mathrm{mg})$. They would have eaten more sodium (about 560 v. $148 \mathrm{mg}$ ) and less calcium (1200 v. $1500 \mathrm{mg}$ ) than Eaton \& Konner predicted. Only the $130 \mathrm{~g}$ fibre/d seems exceptional by today's standards, although the archaeological evidence based on coprolite analysis suggests that such large amounts of fibre were typical in other parts of the world (Kliks, 1978).

Writers often comment on the wide range of vegetable foods available to hunter-gatherers which contrasts with the relatively narrow variety of crops produced by agriculture. AA across Australia ate some 300 different fruit species and 150 varieties of roots and tubers. However, we do not know to what extent AA exploited all the species available or limited themselves to an optimal foraging strategy based on relatively few species. In the animal-dominated diets of AA, plants were subsidiaries, not dietary mainstays that we recommend today. It behoves us to consider the ramifications of dietary guidelines which recommend large amounts of plant foods to everyone, including AA. Some of the consequences may include higher rates of NIDDM because the GI of the modern carbohydrate foods is high (Brand Miller \& Colagiuri, 1994).

The link between the major chronic diseases and the typical Western diet is controversial, but evidence for an important causal relationship is steadily accumulating. We agree with Eaton \& Konner (1985) who wrote "It is both intellectually satisfying and heuristically valuable to estimate the typical diet that human beings were adapted to consume during the long course of evolution". The diet of modern hunter-gatherers such as AA may indeed be a reference standard for modern human nutrition and a model for defence against certain diseases of civilization.

The cooperation of Aboriginal collectors and the dietitians of the Northern Territory Department of Health is gratefully acknowledged. Much of the bushfood analysis was funded by research grants from the Australian Institute of Aboriginal Studies and the Sydney University Nutrition Research Foundation.

\section{References}

Brand, J.C., Cherikoff, V, Lee, A. \& Truswell, A.S. (1982). An outstanding food source of vitamin C. Lancet ii, 873. Brand Miller, J.C. \& Colagiuri S. (1994). The carnivore connection: dietary carbohydrate in the evolution of non-insulin dependent diabetes. Diabetologia 37, 1280-1286.

Brand Miller, J.C., James, K.W. \& Maggiore, P.M. (1993). Tables of Composition of Australian Aboriginal Foods. Canberra: Aboriginal Studies Press.

Brown, A.J. (1985). Fatty Acids in Indigenous Australian Foods. BSc(Hons) thesis. Department of Biochemistry, University of Sydney.

Cleland, J.B. \& Johnston, T.H. (1937). Notes on native names and use of plants in the Musgrave Ranges. Oceania 8 , 208-215.

Cleland, J.B. \& Johnston, T.H. (1938). Notes on native names and use of plants in the Musgrave Ranges region. Oceania 8, 328-342.

Cribb, A.B. \& Cribb, J.W. (1974). Wild Food in Australia. Sydney: Collins.

Eaton, S.B. \& Konner, M. (1985). Paleolithic nutrition. A consideration of its nature and current implications. New England Journal of Medicine 312, 283-289. 
Flood, J. (1995). Archaeology of the Dreamtime: the story of prehistoric Australia and its people, 2nd edn. Pymble, NSW, Australia: Collins Angus and Robertson.

Golson, J. (1971). Australian Aboriginal food plants: some ecological and cultural-historical implications. In Aboriginal Man and Environment, pp. 196-238 [D.J. Mulvaney and J. Golson, editors]. Canberra: Australian National University Press.

Gould, R.A. (1969). Subsistence behaviour among the Western Desert Aborigines of Australia. Oceania 39, $253-274$.

Grant, W.S.R. \& Buttrose, M.S. (1978). Santalum fruit: domestication of the quandong, Santalum acuminatum. Australian Plants 9, 316-318.

Harwood, C.E. (1994). Human food potential of the seeds of some Australian dry-zone Acacia species. Journal of Arid Environments 27, 27-35.

Incoll, L.D., Bonnett, G.D. \& Gott, B. (1989). Fructans in the underground storage organs of some Australian plants 'used for food by Aborigines. Journal of Plant Physiology 134, 196-202.

Irvine, F.R. (1957). Wild and emergency foods of Australian and Tasmanian Aborigines. Oceania 28, $113-142$.

Jelliffe, E.F.P. \& Jelliffe, D.B. (1982). Adverse Effects of Foods. New York: Plenum Press.

Kirk, R.L. (1983). Aboriginal Man Adapting. Melbourne: Oxford University Press.

Kliks, M. (1978). Paleodietetics: a review of the role of dietary fiber in preagricultural human diets. In Topics in Dietary Fiber Reseach, pp. 181-202 [G.A. Spiller and R.F. Amen, editors]. New York: Plenum Press.

Kortt, A. (1985). Some anti-nutritional factors in Acacia seeds. In The Food Potential of Seeds from Australian Native Plants. [G.P. Jones, editor]. Victoria: Deakin University Press.

Lee, A. (1996). The transition of Australian Aboriginal diet and nutritional health. World Review of Nutrition and Dietetics 79, 1-52.

Levitt, D. (1981). Plants and People: Aboriginal uses of plants on Groote Eylandt. Canberra: Australian Institute of Aboriginal Studies Press.

Liener, I.E. (1979). Heat labile anti-nutritional factors. In Advances in Legume Science, pp. 157-159 [R.J. Summerfield and A.H. Bunting, editors]. Kew: Royal Botanic Gardens.

Low T. (1991). Wild Food Plants of Australia. Pymble, NSW, Australia: Angus \& Robertson.

Meggitt, M.J. (1957). Notes on the vegetable foods of the Walbiri of Central Australia. Oceania 28, 143-145.

Murray, D.R., Ashcroft, W.J., Seppelt, R.D. \& Lennox, F.G. (1978). Comparative biochemical and morphological studies of Acacia sophorae (Labill.) R.Br, and A. longifolia (Andrews) Willd. Australian Journal of Botany 26, 755771 .

O'Connell, J.F., Latz P.K. \& Barnett, P. (1983). Traditional and modern plant use among the Alyawarra of Central Australia. Economic Botany 37, 80-109.

Paul, A.A. \& Southgate, D.A.T. (1978). McCance and Widdowson's The Composition of Foods. London: HMSO.

Pauling, L. (1975). Vitamin $C$ and the Common Cold. San Francisco CA: Freeman.

Pettigrew, C.J. \& Watson, L. (1975). On the classification of Australian acacias. Australian Journal of Botany 23, 833847.

Rivett, D.E., Jones, K.G.P., Tucker, D.J. \& Sedgely, M. (1971). The chemical composition of kernels of Santalum species. In The Fatty Acid Composition of the Seed Oils of Proteaceae: a chemotaxonomic study [J.R. Vickery, editor]. Phytochemistry 10 (Suppl.) 123-130.

Rivett, D.E., Jones K.G.P., Tucker D.J. \& Sedgley, M. (1985). The chemical composition of kernels of Santalum species. In The Food Potential of Seeds from Australian Native Plants, pp. 75-92 [G.P. Jones, editor]. Victoria: Deakin University Press.

Salmeron, J., Ascherio, E.B., Rimm, G.A., Colditz, D., Spiegelman, D., Jenkins, D.J., Stampfer, M.J., Wing, A.L. \& Willet, W.C. (1997a). Dietary fiber, glycemic load, and risk of NIDDM in men. Diabetes Care 20, 545-550.

Salmeron, J., Manson, J.E., Stampfer, M.J., Colditz, G.A., Wing, A.L. \& Willet, W.C. (1997b). Dietary fiber, glycemic load and risk of non-insulin-dependent diabetes mellitus in women. Journal of the American Medical Association 277, 472-477.

Specht, R.L. (1958). An introduction to the ethnobotany of Arnhem Land. In Records of the American-Australian Scientific Expedition to Amhem Land, vol. 3, Botany and Plant Ecology [R.L.Specht and C. P. Mountford, editors]. Melbourne: Melbourne University Press.

Sweeney, G. (1947). Food supplies of a desert tribe. Oceania 17, 289-299.

Thorburn, A.W., Brand, J.C. \& Truswell, A.S. (1987a). Slowly digested and absorbed carbohydrate in traditional bushfoods: a protective factor against diabetes? American Journal of Clinical Nutrition 45, 98-106.

Thorburn, A.W., Brand, J.C., O’Dea, K., Spargo, R.M. \& Truswell, A.S. (1987b). Plasma glucose and insulin responses to starchy foods in Australian Aborigines: a population now at high risk of diabetes. American Journal of Clinical Nutrition 46, 282-285.

Toms, G.C. \& Western, A. (1971). Phytohaemagglutinins. In Chemotaxonomy of the Leguminosae, pp. $367-462$ [J.B. Harborne, D. Boulter and B.L. Turner, editors]. London: Academic Press.

Zimmet, P. (1982). Type 2 (non-insulin-dependent) diabetes - an epidemiological overview. Diabetologia $22,399-409$. 